\title{
二次元乱流噴流の速度・圧力場の特性に関する研究*
}

\author{
酒井康 彦*1, 森口優*2, 田中伸彦*3 \\ 山本 睦*4, 久保 貴*5, 長田孝二*1

\section{Study on Characteristics of Velocity and Pressure Field in Two Dimensional Turbulent Jet}

\author{
Yasuhiko SAKAI, Yuu MORIGUCHI ${ }^{* 6}$, Nobuhiko TANAKA, \\ Mutsumi YAMAMOTO, Takashi KUBO and Kouji NAGATA \\ ${ }^{* 6}$ Graduate School of Engineering, Nagoya University, \\ Furo-cho, Chikusa-ku, Nagoya-shi, Aichi, 464-8603 Japan
}

\begin{abstract}
A fluctuating static pressure is closely related with a fluctuating velocity in turbulent flow, and it plays an important role in the energy balance and anisotropy of turbulence. Thus, the measurement of fluctuating static pressure is very effective for clarification of the organized structure of the turbulent flow. In this study, the yaw-insensitive static pressure probe with a good frequency response was developed, and the simultaneous mesurement of velocity and pressure field was carried out in two dimensional jet flow by the combined probe of I-type hot-wire and static pressure probe. In the pressure spectrum, the $\varkappa^{-7 / 3}$ power low could be clearly observed, and the distribution of crosscorrelation between streamwise velocity and static pressure is shown to be consistent with the past model of coherent vortex structure.
\end{abstract}

Key Words : Jet, Fluctuatings Pressure, Turbulent Flow, Flow Measurements, Static Pressure Probe, Kolmogorv's Energy Spectrum

\section{1.はじめに}

乱流を記述する基礎方程式(ここでは，非圧縮性 Navier-Stokes 方程式を考える)には速度変動と共に静 圧変動が含まれ, 静圧変動は乱流のエネルギーバラ ンス, 非等方性乱流の挙動に重要な役割を果たしてい $ろ^{(1)}$. 従って, 乱流の動力学的特性を理解するには変 動速度場と変動静圧場に対する結合統計量の情報が有 効となる.

本研究の目的は, 基本的な乱流場である二次元乱流 噴流において, 変動速度場と変動静圧場の同時測定を 行なうことにより, 二次元噴流の動力学的特性, 特に コヒーレント構造の発展を明らかにすることである.

上記の目的を達成するには, まず, 乱流中の静圧変 動を高分解能で測定できるプローブの開発が不可欠で

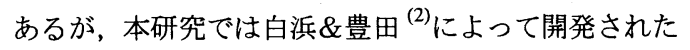
コンデンサマイクロホン使用の静圧プローブを基本に

* 原稿受付 2006 年 3 月 24 日.

*1 正員, 名古屋大学大学院工学研究科 (业464-8603 名古屋市 千種区不老町).

*2 学生員, 名古屋大学大学院工学研究科.

*3 正員, 三菱重工業 (株) (昰 850-8610 長崎市飽の浦町 1-1).

*4 (株) 豊田自動織機 (画 448-8671 刈谷市豊田町 2-1).

*5 正員, 名古屋大学エコトピア科学研究所.

E-mail : yuu_mori@sps.mech.nagoya-u.ac.jp
し, さらにより小型の半導体圧カセンサーを用い, 流 れに対する傾きに対して鈍感で, かつ出来るだけ共振 周波数の高い変動静圧プローブの設計・開発を試みた. そして, 自作した変動静圧プローブと I 型熱線プロー ブを用いて二次元噴流の速度・圧力場の同時測定を行 い, 乱流の統計的特性や噴流構造について考察したの で,これらについて報告する.

\section{2. 変動静圧プローブ}

2.1 変動静圧プロープの設計に対する留意点 変 動静圧の計測法については文献 (3)に詳しく記載されて いるが,ここでは実際に今回, 変動静圧プローブを設

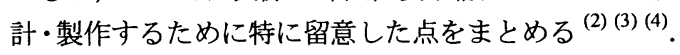
理想的に変動静圧を計測するには計器を流れと共に 流動させて静圧を読み取ることが必要であるが，これ は実際上困難であり，流れ内部で静圧を測る場合には 空間中に固定した静圧管を用いることが一般的である. しかし，静圧管は流れに対する傾きの影響が大きく現 れる.すなわち, 傾きが大きくなれば静圧管に沿う流 れは下流で剥離し，管の周囲で圧力の不均一が起きる. そのため, 静圧の計測には流れをできるだけ乱さない ことが必要な条件である. 従って, 流れを乱すことな 
く，流れに対する傾きに鈍感な静圧管を開発すること は非常に重要である.

また, 静圧管を用いて変動静圧を測定する際, その 静圧管の共振周波数が問題となる. 図 1 に示すような 形状の静圧管プローブがあるとする. 図中, $p_{1}$ は測圧 孔にかかる圧力の值 (これは, 導管内の圧力の值と近 似的に同じであると考えられる)であり， $p_{2}$ は実際に 測定される受圧室での圧力の值である. また, $d_{1}, d_{2}$ はそれぞれ導管の内径及び受圧室の内径に対応し， $l_{1}$ は測圧孔から受圧室までの距離, $l_{2}$ は受圧室の梁さで ある.このとき, 静圧管全体のへルムホルツ共振周波 数 $f_{n 1}$, 及びオルガンパイプ共振周波数 $f_{n 2}$ は

$$
\begin{gathered}
f_{n 1}=\frac{c_{0}}{2 \pi} \frac{d_{1}}{d_{2}} \sqrt{\frac{1}{k l_{1} l_{2}}}, \quad k=1+\frac{8 d_{1}}{3 \pi l_{1}} \\
f_{n 2}=\frac{c_{0}}{2 l_{1}}
\end{gathered}
$$

となる ${ }^{(3)}$.ここで, $c_{0}$ は音速である. ヘルムホルツ 共振は導管の断面積 $A_{1}=\pi d_{1}^{2} / 4$ と長さ $l_{1}$ 及び受圧室 空隙の体積 $V_{2}=A_{2} l_{2}$ (ここで, $\left.A_{2}=\pi d_{2}^{2} / 4\right)$ に依存し, 空隙を導管につないだために生じる共振である.これ らの共振周波数を高くすることも静圧管を開発する上 で重要となる. なお, 図 1 中に示されている $q$ は測圧 孔と導管を通って受圧室に流入する体積流量である.

\section{2 円錐先端型静圧管プローブ 本研究で使用} した変動静圧管プローブは, 白浜・豊田が開発した静 圧プローブ(2)を基本にして試作したものである (図 2). 従って, 静圧管の先端部の形状や寸法は白浜・豊田 ${ }^{(2)}$ と同じとした．具体的には，プローブ頭部の形状は長 さ $10 \mathrm{~mm}$ の細い円錐状となっており，導管の外径は $1.0 \mathrm{~mm}$, 内径 $\left(d_{1}\right)$ は $0.8 \mathrm{~mm}$ である. そして, プロー ブ先端から $19.5 \mathrm{~mm}$ と $20.5 \mathrm{~mm}$ の位置に直径 $0.4 \mathrm{~mm}$ の測圧孔が 4 孔ずつ前後 $1 \mathrm{~mm}$ 離して互い違いに配置 されており, 合計 8 孔開いている. 石田ら ${ }^{(4)}$ は, この ように 4 孔の測圧孔を前後に並べ, 合計 8 孔にする ことによって，流れに対する傾きにより鈍感な，すな わち方向特性が良好な静圧管が実現できることを示し た. 従って, 本研究でも石田ら ${ }^{(4)} に$ に従い, 8 孔の静圧 管を製作することにした．なお，プローブ本体の小型 化を目指し，圧カセンサとして超小型の半導体トラン スデューサー(Kulite:XCS-062-5SG) をプローブのフレ ア部に埋め込んだ. 以後, この変動静圧プローブを円 錐先端型静圧管プローブと称する.この円錐先端型静 圧管プローブの共振周波数の理論值は式(1), 式(2)よ り以下のようになる.

$$
f_{n 1} \simeq 12,450 \mathrm{~Hz}, \quad f_{n 2} \simeq 11,160 \mathrm{~Hz}
$$

なお，本実験における二次元噴流の自己保存領域に おける中心軸上での乱流のスケールは，著者らによる 過去の測定結果 ${ }^{(5)}{ }^{(6)}$ からテイラーの横マイクロスケー ルが約 $3 \mathrm{~mm}$ で, コルモゴロフのマイクロスケールは 約 $0.1 \mathrm{~mm}$ と評価されている. よって, 本静圧管プロー ブは, 測圧孔の直径およびそれらの配置から判断して, コルモゴロフ・スケールほどの分解能はないが, テイ ラー・スケール程度の圧力変動までは測定可能である と考えられる.

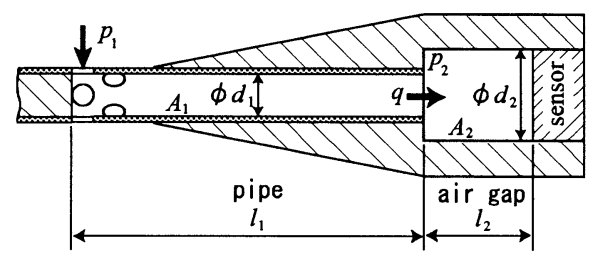

Fig. 1 The schematic of probe

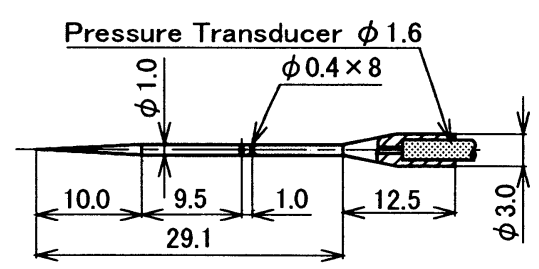

Fig. 2 Static-pressure probe

\section{$2 \cdot 3$ 周波数応答特性検定}

2.3.1 周波数応答特性検定法 図3に示すように, スピーカー(BOSE 社製) から約 $30 \mathrm{~mm}$ 離れた位置に円 錐先端型静圧管プローブの測圧孔がくるように設置し， これと水平に参照用圧カセンサをその受圧面が円錐先 端型静圧管の測圧孔と同じ位置にくるように設置した. そして, オシレーターで発生させた $1,000 \sim 19,000 \mathrm{~Hz}$ の正弦波をオーディオアンプ(BOSE 社製)により増幅 し，スピーカーから音波として放出し，測定を行なう. これらの円錐先端型静圧管プローブと参照用圧力セ ンサにより計測された音波は電圧信号に変換され, セ ンサアンプによって 5,000 倍に増幅されて，このアン プに内蔵されているローパスフィルターを通した後に 電圧計とオシロスコープに取り込まれる. また, オシ レーターで発生した正弦波の波形はオシロスコープに より確認し，位相差を測定する.

参照用圧力センサの振幅測定值及び位相を $p_{1}, \varphi_{1}$, 円錐先端型静圧管プローブの振幅測定值を $p_{2}, \varphi_{2}$ と するとき, 振幅比 $M$ 及び位相差 $\varphi$ を次式のように定 義する ${ }^{(3)}$.

$$
M \equiv p_{2} / p_{1}, \quad \varphi \equiv \varphi_{2}-\varphi_{1}
$$




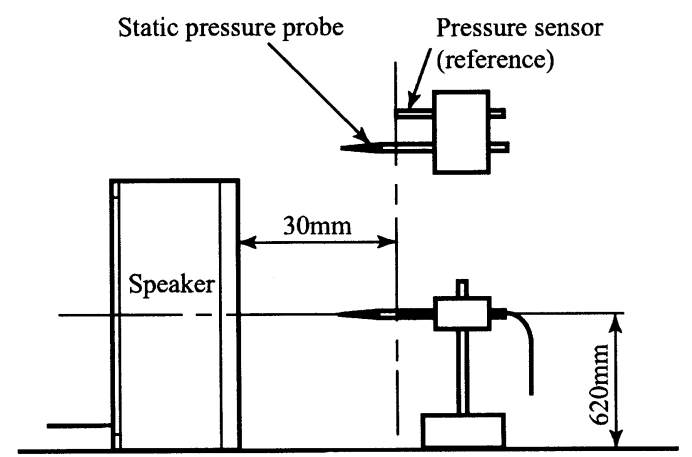

Fig. 3 Experiment of frequency response

\subsection{2 周波数応答特性の検定結果 図 4 に振幅比} $M$ を, 図 5 に位相差 $\varphi$ の実験結果を示す. 実験結果か ら約 $12,000 \mathrm{~Hz}$ で共振点が確認され, 理論值と良い一 致を示していることが分かる. また, 図より, 振幅比 $M$ は約 $3 \mathrm{kHz}$ までほぼ 1 の一定值を示し, 位相差 $\varphi$ も ほとんど $0^{\circ}$ を示している. 従って, 今回試作した円錐 先端型静圧管プローブでは, 周波数が約 $3 \mathrm{kHz}$ までは, ほとんど歪みのない圧力波形が測定できると考えられ る. なお, 後掲する変動圧力スペクトル $E_{p p}$ の分布 (図 $16,18)$ において表示されている無次元波数 $\kappa_{1} \eta\left(\kappa_{1}\right.$ : 噴 流軸方向波数, $\eta$ :コルモゴロフのマイクロスケール) の上限がサンプリング Nyquist 周波数 $5 \mathrm{kHz}$ に対応し ていることを考慮すれば, 図より判断して，圧力スぺ クトル分布は, 周波数 $3 \mathrm{kHz}$ に対応する $\kappa_{1} \eta=10^{-1}$ 程 度までは信頼できるものと考えられる.

\section{4 方向特性検定}

2.4.1 方向特性検定法 円錐先端型静圧管プロー ブの方向特性の検定には正方形噴流風洞 $(80 \mathrm{~mm} \times 80$ $\mathrm{mm})$ を使用し, 出口速度は $U_{0}=15 \mathrm{~m} / \mathrm{s}$ で行なった. 図 6 に示すように，風洞出口の一様流中で静圧管を主 流に対し $|\alpha| \leq 30^{\circ}$ の範囲で傾斜させ，かつプローブ 中心軸周りに $\beta=0,45,90,135^{\circ}$ で回転させて微圧イ ンジケータ (豊田工機 : AA610)により平均静圧值 $P_{\alpha}$ を測定した。測定值は次式により無次元化された.

$$
C_{p}=\left(P_{\alpha}-P_{0}\right) /\left(\rho U_{0}^{2} / 2\right)
$$

ここで, $P_{0}$ は傾斜角 $\alpha=0^{\circ}$ における平均静圧, $U_{0}$ は 出口速度, $\rho$ は密度である.

2.4.2 方向特性の検定結果各種の軸周り回転 角 $\beta$ での主流方向からの傾斜角 $\alpha$ に対する静圧管の 方向特性を図 7 に示す. 図より $|\alpha|<25^{\circ}$ に対して $P_{0}$ とのずれは動圧 $\rho U_{0}^{2} / 2$ に対して約 $2 \%$ であ，方向 特性に優れていることが分かる.

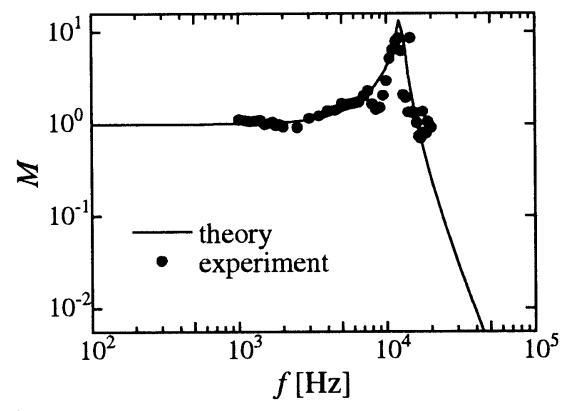

Fig. 4 Amplitude ratio $M$

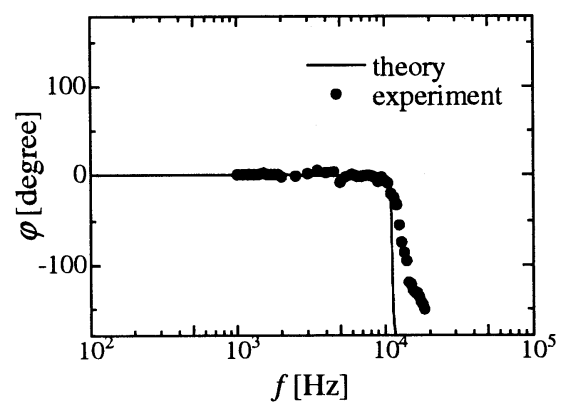

Fig. 5 Phase difference $\varphi$

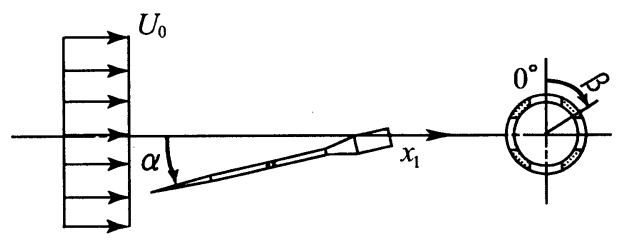

Fig. 6 Yaw angle $(\alpha)$ and rotation angle $(\beta)$

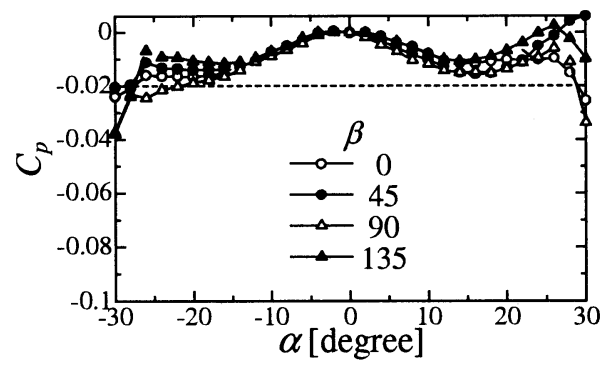

Fig. 7 Yaw angle $(\alpha)$ characteristics of probe

\section{3. 二次元韻流の変動速度と変動静圧の同時測定}

3.1 実験装置と実験条件 本研究で使用した二 次元噴流発生装置は, 著者らによる過去の報告 ${ }^{(7)}{ }^{(8)}$ で 示したものと同じものである. 従って, ここでは装置 の簡単な説明のみ与える (詳細は文献 (7)(8) を参照さ れたい). 図 8 に噴流出口付近の略図と座標系を示す. 
ノズル出ロから $1 \mathrm{~mm}$ 離れた場所にスキマーを設置す ることにより, ノズル出口の流れの均一な部分のみ取 り出すことができる，噴流出口 (スキマー出口) は高さ $d=12 \mathrm{~mm}$ で, アスペクト比は 19.7 である. 座標系は 噴流軸方向を $x_{1}$, 垂直方向を $x_{2}$, スパン方向を $x_{3}$ と し, 噴出レイノルズ数 $\operatorname{Re}$ は $\operatorname{Re}=U_{0} d / v=24,000\left(U_{0}\right.$ :噴 流出口速度)に調節した. 図 9 に速度 ・静圧同時測定 用複合プローブの概略図を示す. 変動速度の測定には I 型熱線プローブ (熱線直径 $5 \mu \mathrm{m}$, 受感部長さ $1 \mathrm{~mm}$ ) を使用し, 変動静圧の測定には今回試作した円錐先端 型静圧管プローブを用いた．また，本研究では自作の 熱線流速計を使用した. I 型熱線プローブと熱線流速 計の周波数応答試験については, 熱線プローブを出ロ 速度が約 $10 \mathrm{~m} / \mathrm{s}$ のポテンシャルコア領域に置き, 熱線 センサー部に掛かる電圧の実効值が $1 \mathrm{~V}$ となるように 正弦波電流を入力して, 交流出力電圧の実効值を測定 した. そして，正弦波に対する周波数応答特性を求め, その結果から求めた時定数により熱線流速計の風速変 動に対する周波数応答特性を評価した. その結果, 本 熱線流速計は約 $10 \mathrm{kHz}$ まで良い周波数応答で測定可 能であることが分かった. 測圧孔から熱線までの間隔 を $1 \mathrm{~mm}$ とし, スパン方向に並列して配置されている. 測定位置は中心軸上, 及び $x_{1} / d=5,10,20,30,40,50$ の各断面で $-2.5 \leq x_{2} / d \leq 2.5$ とした.

なお, 速度場, 圧力場の測定は, 共にサンプリン グ周波数 $10 \mathrm{kHz}$ で行い, 一回のサンプリング点数は 229,376 点であり, デジタルデータをパーソナルコン ピュータに保存した後, 各種統計量を求めた.

\section{2 実験結果及び考察}

3.2.1 平均速度. 半值幅 図 10 に中心軸上の 噴流軸方向の平均速度 $U_{m}$ を示す. 図中 ○, - 印は $\mathrm{Re}=16,000$ におけるX 型熱線プローブ 1 本による過 去の結果 ${ }^{(7)}$ を, $\Delta, \Delta$ 印は $\mathrm{Re}=24,000$ における今回 の実験の同時測定用プローブによる結果を表している. $\operatorname{Re}$ 数が異なることにより若干のずれはあるが両者の 减衰特性は良く一致している. 発達した二次元噴流の 平均速度の中心軸上変化は, 仮想原点からの下流方向 距離の-1/2 乗に比例することが知られている ${ }^{\left({ }^{(9)}\right.}$ が, 本 研究でも $x_{1} / d=5.0$ 以降, その傾向を示していること が分かる. 今回の実験データに対して最小二乗法で直 線近似したところ次式を得た.

$$
\left(\frac{U_{0}}{U_{m}}\right)^{2}=0.143\left(\frac{x_{1}}{d}+2.125\right)
$$

図中の実線はこの近似直線で, 破線はX型熱線プロー ブ 1 本による過去の結果 ${ }^{(7)}$ の近似直線である.

図 11 に平均速度の半值幅 $b$ の変化を示す. この図 において, 縌軸は噴流出口高さ $d$ で無次元化された半

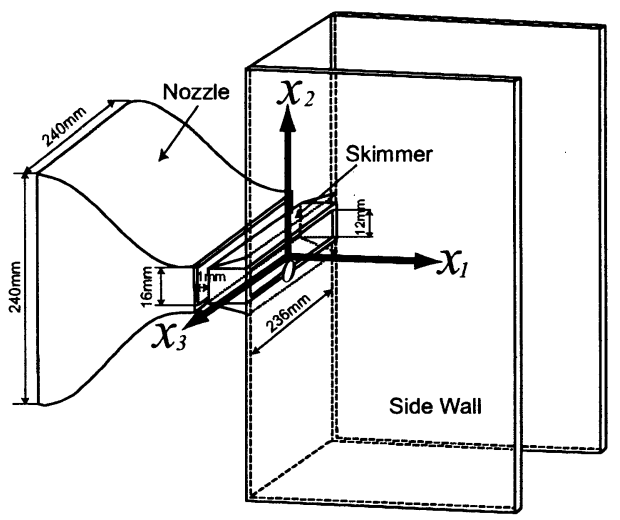

Fig. 8 Coordinate system of Two-dimensional jet flow

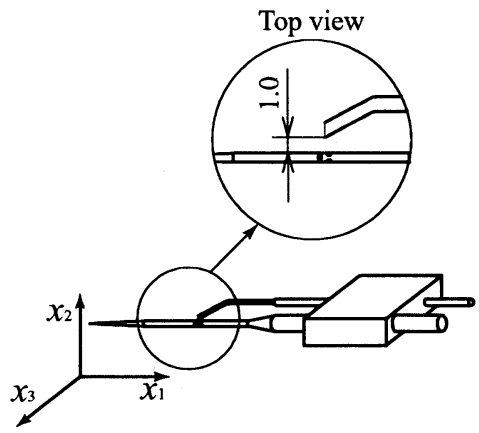

Fig. 9 Combined sensor of I-type hot-wire and pressure probe

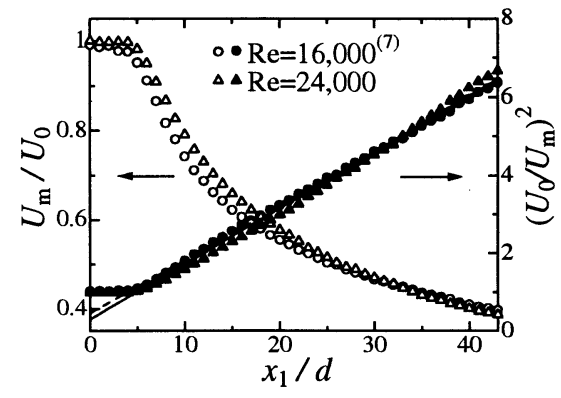

Fig. 10 Axial variation of centerline mean streamwise velocity

值幅を, 横軸は噴流出口高さで無次元化された下流方 向の距離を示している. 図中・印が $\mathrm{Re}=16,000$ での 過去の結果 ${ }^{(7)}$, ○ 印が $\mathrm{Re}=24,000$ の今回の結果であ る. 図より, Re 数が異なるため若干のずれはあるが 両者の発達特性はほぼ一致している.

平均速度の半值幅は発達した二次元噴流では仮想原

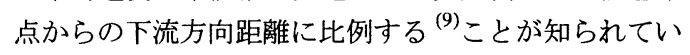
る. 本研究でも $x_{1} / d \geq 5.0$ で $b / d$ がその傾向を示して いることが分かる. 今回の実験データに対して, 最小 


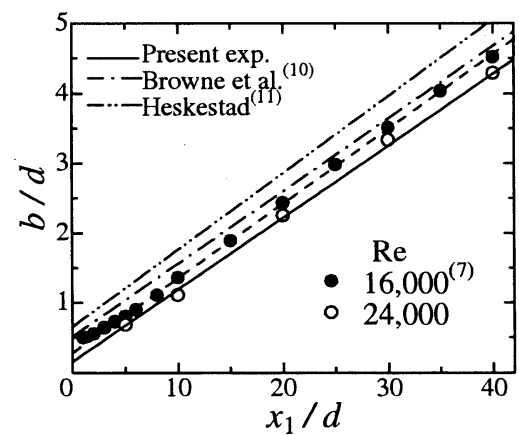

Fig. 11 Downstream variation of halfwidth

二乗法で直線近似したところ次式を得た。

$$
\frac{b}{d}=0.103\left(\frac{x_{1}}{d}+1.54\right)
$$

図中の実線はこの近似直線で, 破線は X 型熱線プロー ブ 1 本による過去の結果 ${ }^{(7)}$ の近似直線である. なお, 参考までに他の研究者による結果 ${ }^{(10)(11)}$ も図中に示し てある. 著者らのデータも含め, 全ての半值幅 $b$ の変 化は良好な直線法則に従い，その傾きはほとんど同じ であることが分かる。

図 12 に噴流軸方向の平均速度 $U$ の $x_{2}$ 方向分布を 示す. 図中, 綐軸は中心軸上の平均速度 $U_{m}$, 横軸は 半值幅 $b$ で無次元化されている. 平均速度分布は相似 になっており，外縁部を除いて Gauss 分布と良く一致 していることが分かる ${ }^{(9)}$.

3.2.2 変動速度・変動静圧図 13 に噴流軸方向 の変動速度 r.m.s 值 $u^{\prime}$ の $x_{2}$ 方向分布を, 図 14 に変 動静圧 r.m.s 值 $p^{\prime}$ の $x_{2}$ 方向分布を示す. 両図とも縦 軸は中心軸上の r.m.s 值で, 横軸は半値幅 $b$ で無次元 化されている，なお，参考までに，図 13 における中 心軸上の変動速度 r.m.s 值 $u_{m}^{\prime}$ は $3.74 \mathrm{~m} / \mathrm{s}\left(x_{1} / d=10\right)$ から $2.26 \mathrm{~m} / \mathrm{s}\left(x_{1} / d=50\right)$ 程度の大きさであり, 図 14 における中心軸上の変動静圧 r.m.s 值 $p_{m}^{\prime}$ の大きさは 12.47Pa $\left(x_{1} / d=10\right)$ から $3.77 \mathrm{~Pa}\left(x_{1} / d=50\right)$ 程度であ った.

図 13 より $u^{\prime}$ は $x_{1} / d \geq 20$ で，どの断面においても相 似な分布を示していることが分かる，なお，図にはX 型熱線プローブ 1 本により測定された $x_{1} / d \geq 20$ の自 己保存領域における結果 ${ }^{(7)}$ が実線で示されているが, 今回の結果とほぼ同様な分布を示している. 一方, $p^{\prime}$ に関しては， $x_{1} / d \geq 20$ の各断面に対して非常に良い 相似分布を示している. なお， $u^{\prime}, p^{\prime}$ とも $x_{2} / b=0$ に おける值が小さく, その左右 $\left(x_{2} / b \simeq \pm 1.0\right)$ において ピークを持つ同様な形状を示すのが特徽的である.

3.2.3 スペクトルおよび相互相関係数図 15, 図 16 に中心軸上における噴流軸方向の変動速度 $u$ のス

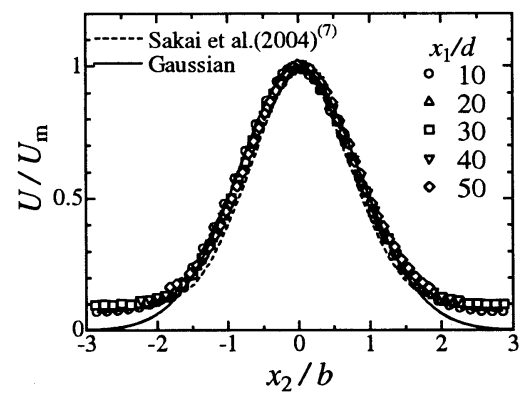

Fig. 12 The cross-streamwise profiles of the mean streamwise velocity

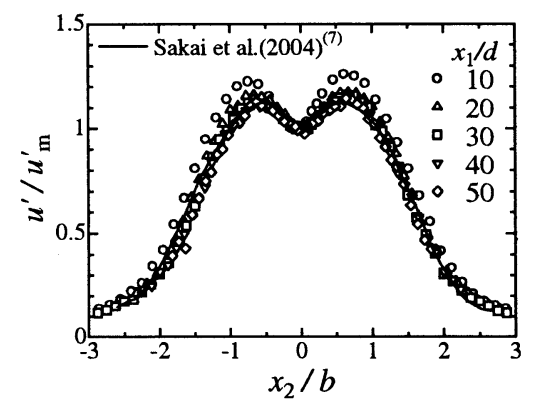

Fig. 13 The cross-streamwise profiles of the r.m.s streamwise velocity

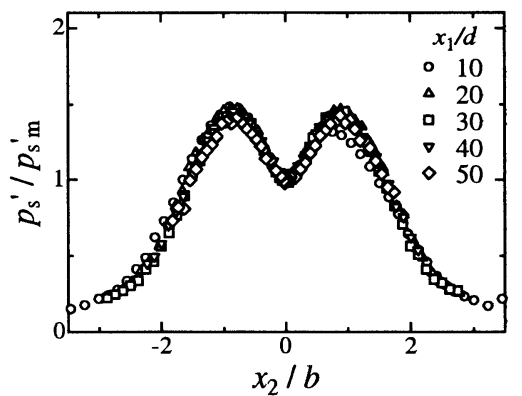

Fig. 14 The cross-streamwise profiles of the r.m.s static pressure

ペクトル $E_{u u}$ の変化及び変動静圧 $p$ のスペクトル $E_{p p}$ の変化をそれぞれ示す。縦軸は単位質量当たりのエネ ルギ一散逸率 $\varepsilon$ と動粘度 $v$ で無次元化し, 横軸は噴流 軸方向の波数 $\kappa_{1}$ をコルモゴロフのマイクロスケール $\eta$ により無次元化している. ここで, $\varepsilon$ と $\eta$ は等方性 乱流場を仮定して次式で評価された.

$$
\begin{gathered}
\varepsilon=2 \nu \cdot \int_{0}^{\infty} \kappa^{2} E(\kappa) d \kappa \\
\eta=\left(\frac{v^{3}}{\varepsilon}\right)^{\frac{1}{4}}
\end{gathered}
$$




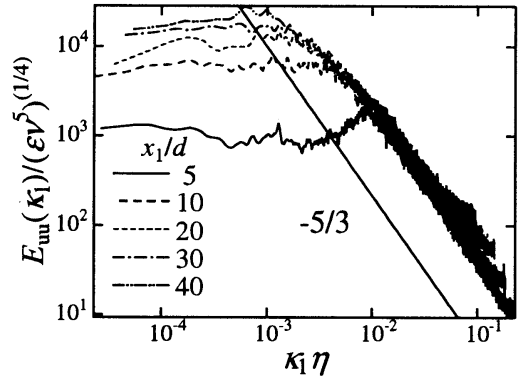

Fig. 15 Power spectra of fluctuating velocity on the centerline

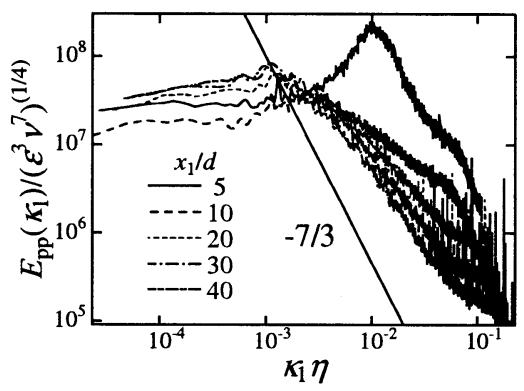

Fig. 16 Power spectra of fluctuating static pressure on the centerline

ここで, $E(\kappa)$ は $u$ あるいは $p$ に対する三次元パワー スペクトルであり, 一次元パワースペクトル $E_{1}\left(\kappa_{1}\right)$ か ら次式により計算された ${ }^{(12)}$.

$$
E(\kappa)=\frac{1}{2}\left[\kappa_{1}{ }^{3} \frac{d}{d \kappa_{1}}\left\{\frac{1}{\kappa_{1}} \frac{d}{d \kappa_{1}} E_{1}\left(\kappa_{1}\right)\right\}\right]_{\kappa_{1}=\kappa}
$$

なお, $E_{1}\left(\kappa_{1}\right)$ は一次元周波数スペクトル $E_{1}(f)$ からテ イラーの仮説を使用して計算している. また, 2.3 .2 節 にて記述したように，スペクトル分布で表示されてい る上限の無次元波数は Nyquist 周波数 $5 \mathrm{kHz}$ に対応し ていることに注意されたい.

図 15 より，中心軸上において $E_{u u}$ は比較的上流側 $\left(x_{1} / d \geq 10\right)$ から- $5 / 3$ 乗を示す領域が存在することが分 かる. 一方, 図 16 より, $E_{p p}$ に対しては明瞭な-7/3 乗 は示されていないが，下流方向に行くに従い，-7/3 乗 の傾きに近づく椂子が確認される. また, ポテンシャ ルコア領域 $\left(x_{1} / d=5.0\right)$ において $E_{u u}, E_{p p}$ ともに明確 なスペクトルのピークが確認できる.このことから， この領域では周期的な渦の放出があることが分かる. なお，下流に行くに従い低波数成分が成長しているた め, そのピークが小さくなっている.これは，混合層 による相互作用を受けるために乱れが增え，いろいろ な波数成分が作られていくためであると考えられる ${ }^{(8)}$.

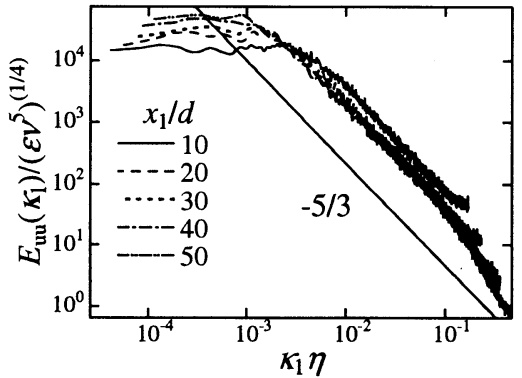

Fig. 17 Power spectra of fluctuating velocity at $x_{2} / b \simeq$ 1.0

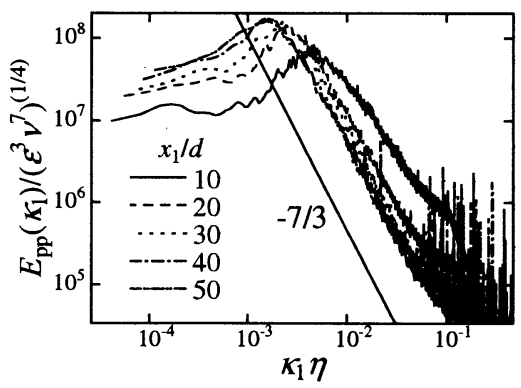

Fig. 18 Power spectra of fluctuating static pressure at $x_{2} / b \simeq 1.0$

図 17 , 図 18 に $x_{2} / b \simeq 1.0\left(u^{\prime}, p^{\prime}\right.$ がピークを持つ位 置)における $E_{u u}$ と $E_{p p}$ の下流方向変化をそれぞれ示 す. 図 17 と図 15 を比較することにより， $x_{2} / b \simeq 1.0$ での $E_{u u}$ は中心軸上の $E_{u u}$ よりも-5/3 乗則が成立する 範囲が広くなっていることが分かる. また, 図 18 と 図 16 を比較すると分かるように, $E_{p p}$ に対して，中 心軸上では明膫でなかった $-7 / 3$ 乗則が $x_{2} / b \simeq 1.0$ に おいては $x_{1} / d \geq 20$ で明瞭に確認される.

以上の結果より, 本二次元噴流においては, 中心軸 付近よりも平均せん断速度の大きな $x_{2} / b \simeq 1.0$ 付近に おいて, 局所等方性に近い普遍平衡領域が実現されて いると考えられる.

図 19 に $x_{1} / d=10,20,30,40$ の各断面の $x_{2} / b \simeq$ $0.0,0.5,1.0,1.5$ における変動速度・変動静圧の相 互相関係数 $R_{u p}$ の分布を示す. 相互相関係数 $R_{u p}$ は次 式で定義される.

$$
R_{u p}(\tau)=\langle u(t) p(t+\tau)\rangle /\left(u^{\prime} p^{\prime}\right)
$$

ここで, $u(t), p(t)$ はそれぞれ $x_{1}$ 方向変動速度, 変動 静圧を示し,〈〉は時間平均を示す. 図上り, 中心軸上 では相関の值は小さいけれども, $x_{2} / b \simeq 0.5,1.0\left(u^{\prime}, p \prime\right.$ が大きな位置) では，遅れ時間 $\tau$ が負のとき正の相関 を示し，遅れ時間 $\tau$ が正へと進むにつれ相関が小さく 
なり，その後負のピークを示すことが分かる．これら の相互相関係数の変化から, 図 20 に示寸ような渦構造 が予想できる. すなわち，速度増加に対して $\tau<0$ (図 中で $t$ で示されている基準点より下流側) では, 周囲 流体の巻き込みと外縁への噴出により圧力が高まる. $\tau>0$ (基準点より上流側) では後方の渦構造により圧 力が下がると考えられる. なお，このような洞構造は Antonia ら ${ }^{(13)}$ が提案したものと矛盾しないものである.

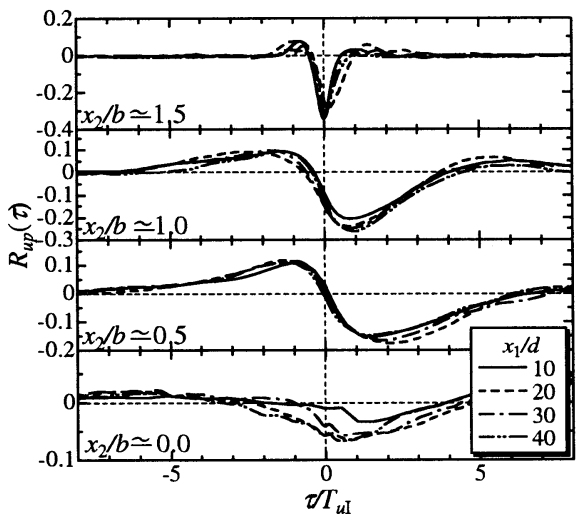

Fig. 19 Distribution of the cross-correlation coefficient

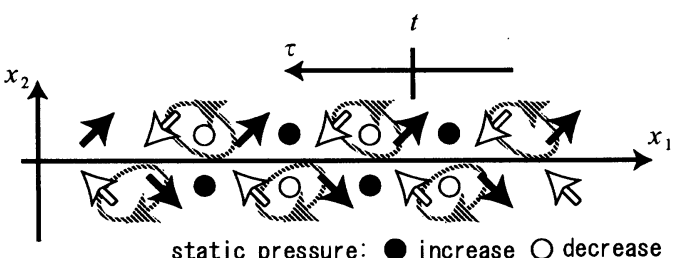

Fig. 20 Model for the vortex structure

\section{4.おわりに}

本研究で得られた結果を以下にまとめる.

1. 自作した円錐先端型静圧管プローブの角度特性を 調べた結果, 主流に対して, 傾斜角が約 $\pm 25^{\circ}$ の

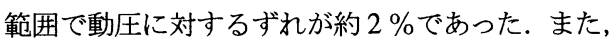
周波数応答を調べた結果, 約 $12 \mathrm{kHz}$ に共振周波 数があることが確認され，本プローブが良好な周 波数特性を示すことが分かった.

2. 二次元噴流場において, 変動静圧 r.m.s 值がピー クを持つ位置では変動静圧のスペクトルに-7/3 乗 則の領域が確認された。

3. 変動速度 - 変動静圧の相互相関 $R_{u p}(\tau)=$ $\langle u(t) p(t+\tau)\rangle /\left(u^{\prime} p^{\prime}\right)$ の分布を調べた結果, $u^{\prime}, p^{\prime}$ の值が大きな位置では, 遅れ時間 $\tau$ が負のとき 正の相関を示し，遅れ時間 $\tau$ が正へと進むにつ れ負の相関を示す。
謝辞

本研究を遂行するにあたり，多大のご教示を頂きま した北海道工業大学豊田国昭先生に深く感謝いたしま す.なお，静圧プローブの製作には (財) 鉄道総合技術 研究所 (委託研究 N512041R) から一部財政的な援助を 頂きました。また，(株)デンソーからは，技術的な支 援を頂きました。ここに記して謝意を表します。

\section{文献}

(1) Pope, S.B., Turbulent Flows, (2000), Chapter 7,pp.264 332, and Chapter 11,pp.387-462, Cambridge University Press.

(2) Shirahama, Y. and Toyoda, K., Development of the Probe to Measure Static-Pressure Fluctuations(Application to the Measurements of Jets), Transactions of the Japan Society of Mechanical Engineers, Series B, Vol.59, No.567(1993), pp.3381-3387.

(3) The Japan Society of Mehanical Engineers ed., JSME Data Book:Flow Measurements, (1985), pp.34-66, The Japan Society of Mehanical Engineers.

(4) Ishida, T. et al., Study of Yaw-Angle Characteristics of Static Pressure Probe, Proceedings of Fluids Engineering Division Conference of the Japan Society of Mechanical Engineers, No.95-19(1995), pp.169-170.

(5) Tanaka, N., An Experimental Study on the Development of Coherent Structure in a Plane Jet, ph. D. Thesis, Nagoya University, (2005).

(6) Tanaka, N. et al., A Study on the Realization of a Turbulent Plane Jet with the High Two-Dimensionality by Means of Both the Skimmer and the Side Wall, and Investigation of its Fundamental Property, Fluid \& Heat Engineering Reseach, Vol.39, No.1(2004), pp.9-16.

(7) Sakai, Y. et al., An Experimental Study on the Development of Coherent Structure in a Plane Jet(1st Report:Distributions of Two-point Spatial Velocity Correlation and Analysis of Eigenmodes by the KL Expansion), Transactions of the Japan Society of Mechanical Engineers, Series B, Vol.70, No.697(2004), pp.103-110.

(8) Sakai, Y. et al., An Experimental Study on the Development of Coherent Structure in a Plane Jet(2nd Report, Spatio-temporal Velocity Structure by the Combined Analysis of KL Expansion and Fourier Transform), Transactions of the Japan Society of Mechanical Engineers, Series B, Vol.71, No.708(2005), pp.1978-1985.

(9) Rajaratnam, N., Turbulent Jet, (1976), pp.1-26, Elsevier Scientific Publishing Company.

(10) Browne, L.W.B. et al., The Interaction Region of a Turbulent Plane Jet, Journal of Fluid Mechanics, (1984), Vol.134, pp.355-373.

(11) Heskestad, G., Hot-wire Measurements in a Plane Turbulent Jet, Journal of Applied Mechanics, Vol.32, (1965), pp.721-734.

(12) Hinze, J.O., Turbulence, Second edition, (1975), Chaper 3, pp.175-319, McGraw-Hill, Inc.

(13) Antonia, R.A. et al., On the Organized Structures of a Turbulent Plane Jet, Journal of Fluid Mechanics, Vol.134, (1983), pp.49-66. 